\title{
Influence of Chronic Lactulose Ingestion on the Colonic Metabolism of Lactulose in Man (An In Vivo Study)
}

\author{
Christian Florent, Bernard Flourie, Annie Leblond, Michèle Rautureau, Jean-Jacques Bernier, \\ and Jean-Claude Rambaud \\ Inserm U54, Hôpital Saint-Lazare, 75475 Paris Cedex 10, France
}

\begin{abstract}
The effects of a chronic load of nonabsorbable sugars on intracolonic bacterial metabolism of carbohydrates and on $\mathbf{H}_{2}$ breath excretion are disputed. However, most of the discussion relies on indirect evidence or on results of in vitro studies. Thus, we attempted to assess directly and in vivo the effects on intracolonic metabolism of lactulose of a chronic oral load of this nonabsorbable disaccharide. $20 \mathrm{~g}$ of lactulose was given orally twice daily during $8 \mathrm{~d}$ to eight normal volunteers. In all, breath $\mathrm{H}_{2}$ concentration was measured on days 1 and 8 after ingestion of the morning lactulose dose. In four subjects, stools were collected during $2 \mathrm{~d}$ at the beginning and at the end of the lactulose maintenance period to measure fecal $\mathrm{pH}$ and daily outputs of carbohydrates and $\beta$-galactosidase. The four other subjects were intubated on days 1 and 8 to measure the pH and the concentrations of carbohydrates, lactic acid, and volatile fatty acids (VFA) in the distal ileum and cecal contents. Moreover, ${ }^{14} \mathrm{C}$-lactulose was added to cold lactulose and ${ }^{14} \mathrm{CO}_{2}$ breath outputs determined. Pulmonary $\mathrm{H}_{2}$ excretion fell from day 1 to day $8(P<0.05)$, whereas ${ }^{14} \mathrm{CO}_{2}$ excretion increased $(P<0.01)$. Fecal water $\mathrm{pH}$, lactic acid, and VFA concentrations did not vary between the two stool collection periods. 24-h fecal weight, fecal water, and carbohydrate outputs showed a trend to decrease between days 1 and 2 and days 7-8, whereas $\beta$-galactosidase activity rose markedly $(P<0.01)$. No significant variations were observed for all parameters measured in ileal fluid. In the cecum, areas under the concentration curves decreased from day 1 to day 8 for lactulose, galactose, and fructose $(P<0.01)$, while an increase was found for lactic acid $(P<0.001)$, acetic acid $(P<0.0001)$, and total VFA $(P<$ $0.001)$. Cecal fluid pH dropped faster $(P<0.05)$ and to a lower level $(P<0.05)$ on day 8 than on day 1 . These data clearly show that a chronic load of a nonabsorbable sugar induces changes in colonic bacterial metabolic pathways resulting in a better efficiency of the flora to digest the carbohydrate.
\end{abstract}

\section{Introduction}

Measurement of pulmonary hydrogen $\left(\mathrm{H}_{2}\right)$ excretion is widely used to diagnose and quantify carbohydrate malabsorption (1-6). However the accuracy of the $\mathrm{H}_{2}$ breath test in the study of chronic carbohydrate malabsorption is debated (1). Perman et al. (7) showed that an 8-d oral administration of lactulose resulted in acidic stools and in a dramatic fall of $\mathbf{H}_{2}$ breath excretion after an oral load of this sugar or of lactose in

Received for publication 1 August 1984.

J. Clin. Invest.

(c) The American Society for Clinical Investigation, Inc.

0021-9738/85/02/0608/06 \$1.00

Volume 75, February 1985, 608-613 lactase-deficient patients. From stool homogenate incubations with various sugars, these authors concluded that the fall of $\mathrm{H}_{2}$ production was due to an inhibition of bacterial carbohydrate metabolism by the low colonic $\mathrm{pH}$ (7). Unfortunately, they did not measure stool sugar outputs. If their statement was always true, lactose- $\mathrm{H}_{2}$ breath test could be erroneously normal in lactase-deficient patients ingesting every day large amounts of incompletely absorbed carbohydrates, including lactose itself. This is contradictory to the high sensitivity of lactose- $\mathrm{H}_{2}$ breath test in the diagnosis of lactase deficiency $(5$, 8). Moreover, in lactase-deficient preterm infants receiving a lactose-containing diet, $\mathrm{H}_{2}$ breath excretion did not decrease with time, and even the amounts of unabsorbed lactose calculated from $\mathrm{H}_{2}$ production correlated well with lactose intakes (5). Fecal pH was not measured in this study. A hypothesis based on colonic flora adaptation to the diet has been proposed to explain these contradictory data (1). However, adaptation of colonic flora population levels or metabolic activities is itself a disputed concept supported by several studies (9-16), but not confirmed by other ones (9, 17-19).

These discrepancies incited us to reinvestigate the effects of a repeated load of an unabsorbable carbohydrate on the intracolonic metabolism (including $\mathrm{H}_{2}$ production) of this sugar. In the first part of our study, Perman et al. (7) protocol design was applied to four normal subjects. Hydrogen breath excretion was found reduced after the 8-d lactulose administration; however, fecal $\mathrm{pH}$ did not decrease and carbohydrates were not excreted in stools, whereas $\beta$-galactosidase fecal output increased significantly. These results suggested that lactulose chronic ingestion did induce a colonic bacterial adaptation in our subjects, and not the inhibition postulated by Perman et al. (7). Thus, in a second group of four normal subjects, biochemical studies were directly performed on cecal fluid after a 20-g lactulose ingestion at the beginning and the end of the lactulose maintenance period. The results strongly suggest both an acceleration of lactulose catabolism and a modification of bacterial metabolic pathways.

\section{Methods}

Human subjects. Studies were performed in eight healthy human volunteers: two women and six men, aged 23-46 yr. All of them were nonmethane-producing subjects $(20,21)$ and had previously a lactose$\mathrm{H}_{2}$ breath test consistent with normal lactose absorption. Informed consent was obtained; the subjects were aware of potential radiation hazards. The protocol was approved by the ethics committee of the Saint-Lazare Hospital.

Experimental design. All subjects remained on their accustomed diet and received twice daily for $8 \mathrm{~d}$ an oral load of $20 \mathrm{~g}$ lactulose (lactulose syrup: Duphar Laboratories, Villeurbanne, France). This will be referred to as the lactulose maintenance period.

(a) In four subjects (group A), 24-h stools were collected on days 1 and 2 (first period) and on days 7 and 8 (second period). Stools were immediately frozen at $-20^{\circ} \mathrm{C}$ for further analysis. Stool weight, $\mathrm{pH}$, 
carbohydrate outputs (lactulose, galactose, fructose, and glucose), $\beta$ galactosidase activity, and volatile fatty acids (VFA) ${ }^{1}$ were measured in total homogeneized stools.

(b) The four other subjects (group B) were intubated on the day before day 1 and on day 7 with a triple lumen tube tracted by a mercury bag which could be inflated with air through lumen 1 to accelerate tube progression. When the mercury bag had reached the cecum, as confirmed by a fluoroscopical check, the tube progression was stopped by deflating the bag and the subject had to stay in a semirecumbent position. Lumen 2, whose end was near the bag, allowed the sampling of cecal content. Lumen 3, ending $15 \mathrm{~cm}$ above lumen 2, was used to collect distal ileum fluid samples. On days 1 and 8 the subjects ingested $20 \mathrm{~g}$ lactulose at $9 \mathrm{a} . \mathrm{m}$. after an overnight fast. 3-ml samples of ileal and cecal contents were obtained every $30 \mathrm{~min}$ during the first $4 \mathrm{~h}$ after lactulose ingestion and every hour during the last $4 \mathrm{~h}$. Ileal and cecal fluids were immediately frozen at $-20^{\circ} \mathrm{C}$ until assayed for osmolality and concentrations of lactulose, galactose, fructose, glucose, lactic acid, and VFA (acetic, propionic, isobutyric, butyric, isovaleric, and valeric acids). $\mathrm{pH}$ was measured before freezing the samples.

Breath $\mathrm{H}_{2}$ concentration was determined in the eight subjects on days 1 and 8 , before and at 30-min intervals for $8 \mathrm{~h}$ after the morning load of $20 \mathrm{~g}$ lactulose. Breath samples were obtained by end-expiratory aspiration of $60-\mathrm{ml}$ aliquots of gaz into plastic syringes equipped with a 3-way stopcocks. Moreover, in subjects of group B, a ${ }^{14} \mathrm{CO}_{2}$ breath test was performed at the same time as $\mathrm{H}_{2}$ breath test by adding 2.5 $\mu \mathrm{Ci}$ of $1{ }^{14} \mathrm{C}$-lactulose. At 30 -min intervals during $4 \mathrm{~h}$ the subjects exhaled into a liquid scintillation vial containing $1 \mathrm{ml}$ of $2 \mathrm{mM}$ of hyamine hydroxyde and a trace of phenolphtalein as $\mathrm{pH}$ indicator (22).

Analytical procedures. After adequate dilution, homogeneized stool, cecal, and ileal fluid samples were ultracentrifuged at $120,000 \mathrm{~g}$ and all measurements were performed on the supernatant. Fecal water volume was obtained by dessication. pH was measured with a Radiometer pHmeter (Radiometer, Copenhagen, Denmark) and osmolality with a Fiske Osmometer (freezing point depression measurement). Lactulose, D-galactose, D-fructose, D-glucose, and lactic acid (both D and $L$ ) concentrations were determined by enzymatic methods (Boehringer Kits, Manheim, Federal Republic of Germany). Volatile fatty acids were measured using high pressure liquid chromatography with ethyl-butyric acid as an internal standard (23). Fecal $\beta$-galactosidase was measured by a colorimetric assay $(24,25)$ using paranitrophenyl beta-D-galactopyranoside at $\mathrm{pH} 7$ as substrate. Enzyme activities were calculated according to International Units per kilogram stool (IU/kg $37^{\circ} \mathrm{C}$ ), $1 \mathrm{IU}$ being the amount of enzyme that hydrolyse $1 \mu \mathrm{mol}$ of substrate per min at $37^{\circ} \mathrm{C}$. Hydrogen concentration in expiratory gaz samples was measured using an electrochemical cell (Exhaled Hydrogen Monitor, GMI Medical Ltd., Renfrew, Scotland). The minimal detectable $\mathrm{H}_{2}$ concentration was $1 \mathrm{ppm} .{ }^{14} \mathrm{C}$ radioactivity was measured in a liquid scintillation counter (Compagnie Gènèrale de Radiologie, Paris, France).

Calculations and statistics. Total excess breath $\mathrm{H}_{2}$ excretion after lactulose oral load was determined by integrating the area under the curve of interval breath $\mathrm{H}_{2}$ concentrations $(6,26)$ and by expressing data in milliliter for the total test period. ${ }^{14} \mathrm{CO}_{2}$ breath output was calculated by multiplying the measured $\mathrm{CO}_{2}$ specific activity for each period by the theoretical $\mathrm{CO}_{2}$ output $\left(9 \mathrm{mmol} \cdot \mathrm{kg}^{-1} \cdot \mathrm{h}^{-1}\right)$. Results were expressed in percent of ingested dose expired for $1 \mathrm{~h} \mathrm{(22).}$

Statistical analysis for significance was performed using paired $t$ test. Results are expressed as mean \pm SEM.

\section{Results}

Effect of lactulose maintenance period on the lactulose- $\mathrm{H}_{2}$ breath test. Hydrogen production was similar in the two groups

1. Abbreviations used in this paper: ppm, parts per million; VFA, volatile fatty acids.

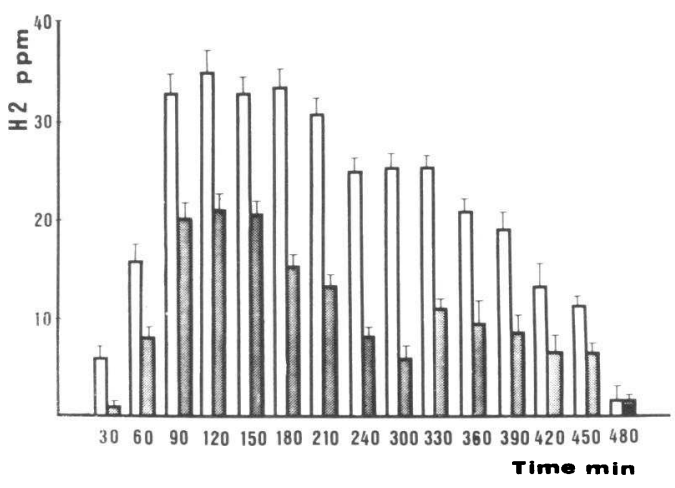

Figure 1. Breath $\mathrm{H}_{2}$ responses to lactulose test doses on day 1 (white columns) and day 8 after the lactulose maintenance period (hatched columns). The average change in $\mathrm{H}_{2}$ concentrations in parts per million above base line for eight subjects is represented by the bars (mean \pm SEM).

during both periods. Basal breath $\mathrm{H}_{2}$ concentrations did not change after the lactulose maintenance period $(9.1 \pm 2.1$ parts per million (ppm) and 9.6 $\pm 5.4 \mathrm{ppm}$ on days 1 and 8 , respectively). Excess breath $\mathrm{H}_{2}$ per $8 \mathrm{~h}$ declined significantly ( $P$ $<0.05$ ) from $15.2 \pm 2.6 \mathrm{ml}$ on day 1 to $8.6 \pm 2.3 \mathrm{ml}$ on day 8 (Fig. 1). The pulmonary excretion of ${ }^{14} \mathrm{CO}_{2}$ per $4 \mathrm{~h}$ significantly increased $(P<0.01)$ from day 1 to day 8 (Fig. 2).

Feces. 24-h fecal weight, fecal water, and carbohydrate (lactulose, galactose, fructose, and glucose) outputs showed a trend to decrease between the first and second periods (Table I). The $\mathrm{pH}$ of fecal water was unaffected by lactulose maintenance $(6.03 \pm 0.35$ and $6.07 \pm 0.25$ for the first and second periods, respectively). The VFA concentrations in fecal water and daily fecal VFA outputs were similar during the two periods (Table II). On the contrary $\beta$-galactosidase fecal concentration increased significantly from $1,078 \pm 380$ to $6,695 \pm 1,792 \mathrm{IU} / \mathrm{g}(P<0.001)$. Finally $\beta$-galactosidase fecal output increased significantly $(P<0.01)$ from $168,618 \pm 33,422$ to $952,872 \pm 354,490 \mathrm{IU} / \mathrm{d}$ between the first and second periods.

Ileal contents. The time of lactulose appearance at the ileal sampling point, the peak concentration, and the total duration of lactulose recovery did not change significantly between days 1 and 8 (Table III). Lactulose concentrations in ileal fluid are shown in Fig. 3. There was no significant change between days 1 and 8 concerning VFA concentration, $\mathrm{pH}$, and osmolality of ileal fluid. Galactose and fructose concentrations on both days were constantly $<1 \mathrm{mM}$ and glucose concentrations $<6 \mathrm{mM}$.

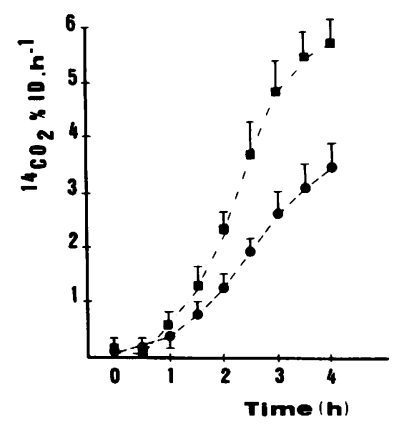

Figure 2. Breath ${ }^{14} \mathrm{CO}_{2}$ output after ingestion of $2.5 \mu \mathrm{Ci}$ of ${ }^{14} \mathrm{C}$ labeled lactulose and $20 \mathrm{~g}$ cold lactulose on day 1 (circles) and on day 8 after the lactulose maintenance period (squares) for four subjects. Bars represent the SEM. ID, ingested dose. 
Table I. 24-H Stool Weight, Fecal pH, and Outputs of Water and Carbohydrates at the Beginning (Day 1-Day 2) and the End (Day 7-Day 8) of the Lactulose Maintenance Period

\begin{tabular}{|c|c|c|c|c|}
\hline & \multicolumn{2}{|c|}{ Day 1-Day 2} & \multicolumn{2}{|c|}{ Day 7-Day 8} \\
\hline & Mean* & Range & Mean* & Range \\
\hline Stool weight $\left(g \cdot d^{-1}\right)$ & 251 & $48-414$ & 159 & $89-210$ \\
\hline Fecal water $\left(m l \cdot d^{-1}\right)$ & 217 & $34-373$ & 131 & $74-159$ \\
\hline Lactulose $\left(\mathrm{mmol} \cdot \mathrm{d}^{-1}\right)$ & 0.00 & $0-0.25$ & 0.00 & $0-0.01$ \\
\hline Galactose $\left(\mathrm{mmol} \cdot \mathrm{d}^{-1}\right)$ & 2.76 & $0.09-7.45$ & 0.68 & $0.16-1.64$ \\
\hline Fructose $\left(\mathrm{mmol} \cdot \mathrm{d}^{-1}\right)$ & 1.62 & $0.00-4.11$ & 0.29 & $0.00-1.07$ \\
\hline Glucose $\left(\mathrm{mmol} \cdot \mathrm{d}^{-1}\right)$ & 2.88 & $0.24-5.11$ & 2.07 & $0.61-3.25$ \\
\hline Total CHO, $\ddagger\left(\mathrm{mmol} \cdot \mathrm{d}^{-1}\right)$ & 7.26 & $0.9-16.67$ & 3.04 & $0.85-4.68$ \\
\hline Stool pH & 6.03 & $5.58-7.32$ & 6.07 & $5.55-7.28$ \\
\hline
\end{tabular}

None of the variations between day 1-day 2 and day 7-day 8 are statistically significant.

$n=4$.

$\ddagger \mathrm{CHO}$, carbohydrates.

\section{Cecal contents}

Lactulose, galactose, fructose. The results of cecal lactulose measurements are summarized in Table IV. Lactulose peak concentration and total duration of recovery decreased significantly from day 1 to day 8 ( $P<0.02$ and $P<0.01$, respectively) (Fig. 4), and this resulted in a reduced $(P<0.01)$ area under the curve of the sugar concentration. In cecal fluid, galactose and fructose were never recovered before lactulose ingestion and appeared in the same sample as lactulose. Galactose and fructose concentration curves were very close to each other and consequently are shown as a single curve on days 1 and 8 (Fig. 5). Individual maximal concentrations of galactose and

Table II. Fecal VFA Concentrations and $24 \mathrm{H}$ Outputs at the Beginning (Day 1-Day 2) and at the End (Day 7-Day 8) of the Lactulose Maintenance Period

\begin{tabular}{lcc}
\hline & Day 1-Day 2 & Day 7-Day 8 \\
\hline Concentration & $\mu \mathrm{mol} / \mathrm{g}$ & $\mu \mathrm{mol} / \mathrm{g}$ \\
Total VFA & & \\
Acetic acid & $97.0 \pm 17$ & $85.2 \pm 5.0$ \\
Propionic acid & $56.8 \pm 13.7$ & $53.5 \pm 5.5$ \\
Butyric + isobutyric acid & $12.2 \pm 1.45$ & $10.6 \pm 1.5$ \\
Isovaleric acid & $14.8 \pm 4.6$ & $13.3 \pm 1.8$ \\
Valeric acid & $5.2 \pm 0.8$ & $2.8 \pm 0.9$ \\
& $8.0 \pm 1.9$ & $5.0 \pm 1.9$ \\
& & \\
24 h outputs & $m m o l \cdot d^{-1}$ & $m m o l \cdot d^{-1}$ \\
Total VFA & & \\
Acetic acid & $22.8 \pm 7.5$ & $11.2 \pm 2.0$ \\
Propionic acid & $14.6 \pm 5.2$ & $7.0 \pm 1.4$ \\
Butyric + isobutyric acid & $2.5 \pm 0.7$ & $1.4 \pm 0.3$ \\
Isovaleric acid & $3.2 \pm 1.3$ & $1.8 \pm 0.4$ \\
Valeric acid & $3 \pm 2$ & $0.4 \pm 0.1$ \\
& $1.49 \pm 0.6$ & $0.6 \pm 0.2$ \\
\hline
\end{tabular}

Data are expressed as mean $\pm \operatorname{SEM}(n=4)$.

None of the variations between day 1-day 2 and day 7-day 8 are statistically significant.
Table III. Lactulose and Total VFA Ileal Recovery, $p H$, and Osmolality of Ileal Fluid After $20 \mathrm{G}$ Lactulose Ingestion on Day 1 and on Day 8 After the Lactulose Maintenance Period

\begin{tabular}{|c|c|c|c|c|}
\hline & \multicolumn{2}{|l|}{ Day 1} & \multicolumn{2}{|l|}{ Day 8} \\
\hline & Mean* & Range & Mean* & Range \\
\hline $\begin{array}{l}\text { Lactulose appearance } \\
\text { time }(\mathrm{min})\end{array}$ & 45 & $30-60$ & 45 & $30-60$ \\
\hline $\begin{array}{l}\text { Lactulose total transit } \\
\text { time }(\min )\end{array}$ & 405 & $240-480$ & 405 & $240-480$ \\
\hline $\begin{array}{l}\text { Time of lactulose peak } \\
\text { concentration ( } \mathrm{min} \text { ) }\end{array}$ & 172.5 & $60-270$ & 210 & $30-300$ \\
\hline $\begin{array}{l}\text { Lactulose peak } \\
\text { concentration }(m M)\end{array}$ & 110 & $83-130$ & 110 & $74-180$ \\
\hline $\begin{array}{l}\text { Total VFA concentratio } \\
\quad(m M)\end{array}$ & 11.5 & $8-15$ & 11.75 & $7-14$ \\
\hline $\begin{array}{l}\text { Mean osmolality } \\
\left(\text { mosmol } \cdot \mathrm{kg}^{-1}\right)\end{array}$ & 309.5 & $233-371$ & 295.4 & $259-321.5$ \\
\hline Mean pH & 7.65 & $7.27-8.22$ & 7.91 & $7.57-8.25$ \\
\hline
\end{tabular}

None of the variations between days 1 and 8 are statistically significant.

$* n=4$.

fructose did not change between days 1 and 8. On the contrary, areas under the curves of fructose and galactose concentrations significantly decreased from day 1 to day $8(P<0.01)$. Finally, $8 \mathrm{~h}$ after lactulose ingestion, galactose and fructose were still recovered in cecal fluid on day $1(10.0 \pm 3.8$ and $3.05 \pm 2.75$ $\mathrm{mM}$, respectively), whereas their concentrations on day 8 were $<1 \mathrm{mM}$ from the sixth hour.

Glucose. In all subjects, glucose was detectable before lactulose ingestion in cecal fluid and its concentration was not modified by the lactulose maintenance period. Cecal glucose concentration gradually increased after lactulose ingestion to a late peak concentration of $18.6 \pm 4.7$ and $9.5 \pm 2.1 \mathrm{mM}$ on days 1 and 8 , respectively $(P<0.01)$.

Lactic acid. Lactic acid (isomeres $\mathrm{D}$ and $\mathrm{L}$ ) concentration curves were very different on days 1 and 8 . On day 1 , lactic acid concentration was still increasing at the end of the sampling period, whereas on day 8 the peak concentration occurred at $225 \pm 50 \mathrm{~min}$ and then the lactic acid concentration decreased (Fig. 6). The highest mean concentrations were

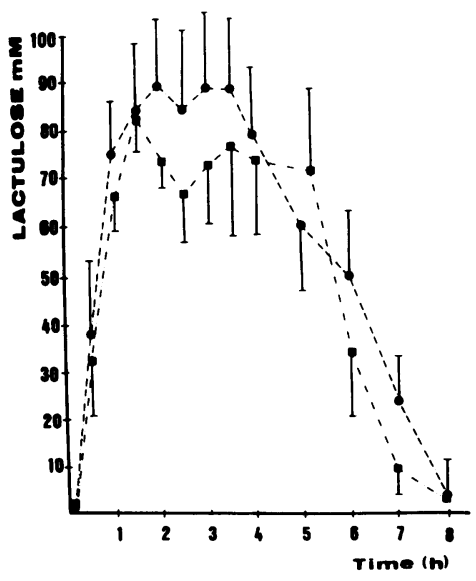

Figure 3. Lactulose concentrations in ileal fluid after $20 \mathrm{~g}$ lactulose ingestion on day 1 (circles) and on day 8 after the lactulose maintenance period (squares) for four subjects. Bars represent the SEM. 
Table IV. Lactulose Cecal Recovery After

20 G Lactulose Ingestion on Day 1 and on

Day 8 After the Lactulose Maintenance Period

\begin{tabular}{lllllll}
\hline & Day 1 & & Day 8 & & \\
\cline { 2 - 3 } & Mean* & Range & & Mean* & Range & $P$ \\
\hline $\begin{array}{l}\text { Orocecal transit } \\
\text { time }(\text { min })\end{array}$ & 60 & $30-90$ & 60 & $30-90$ & NS $\ddagger$ \\
$\begin{array}{c}\text { Peak concentration } \\
(m M)\end{array}$ & 88.5 & $73-112$ & 45.7 & $16-91$ & $<0.02$ \\
$\begin{array}{c}\text { Time of peak } \\
\text { concentration } \\
(\text { min })\end{array}$ & 105 & $90-135$ & 97.5 & $90-120$ & NS \\
$\begin{array}{c}\text { Total recovery } \\
\text { time }(\text { min })\end{array}$ & 390 & $330-420$ & 210 & $90-360$ & $<0.01$ \\
\hline
\end{tabular}

$* n=4$.

$\ddagger N S$, not significant.

$26.9 \pm 6.2$ and $49.5 \pm 10 \mathrm{mM}$ on days 1 and 8 , respectively. The areas under the curves of lactic acid increased significantly from day 1 to day $8(P<0.001)$. The ratio between $L$ and $D$ lactic acid did not change from day 1 to day 8: $1.55 \pm 0.11$ (range 1.27-1.80) and 1.84 \pm 0.17 (range 1.52-2.32), respectively.

Volatile fatty acids. Before lactulose ingestion, neither total VFA concentration nor distribution were significantly different on days 1 and 8 (Table V) (Fig. 7). After lactulose ingestion, the area under total VFA concentration curve and the molar ratio of acetic acid significantly increased from day 1 to day 8 , whereas propionic, butyric, isobutyric, valeric, and isovaleric acid concentrations did not significantly change (Table VI).

pH measurements. Cecal pH before lactulose ingestion was

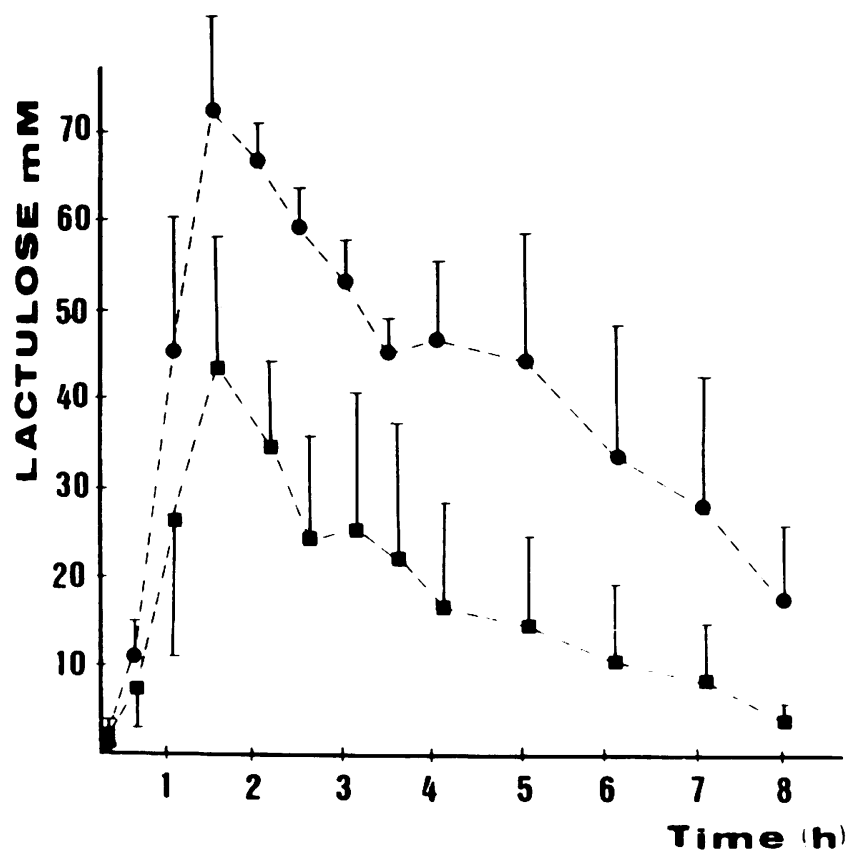

Figure 4. Lactulose concentrations in cecal fluid after $20 \mathrm{~g}$ lactulose ingestion on day 1 (circles) and on day 8 after the lactulose maintenance period (squares) for four subjects. Bars represent the SEM.

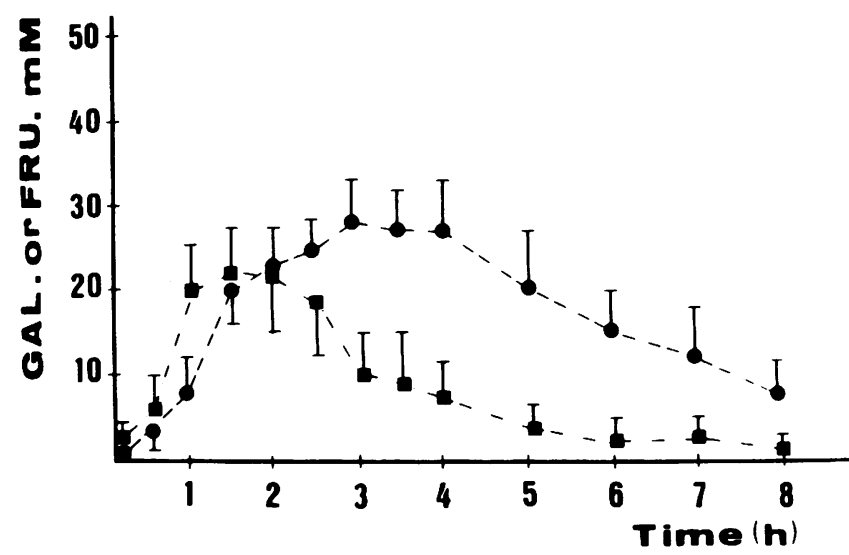

Figure 5. Fructose (FRU) and galactose (GAL) concentrations in cecal fluid after $20 \mathrm{~g}$ lactulose ingestion on day 1 (circles) and on day 8 after the lactulose maintenance period (squares) for four subjects. Bars represent the SEM.

not significantly modified by the lactulose maintenance period. Nadir $\mathrm{pH}$ values were lower $(P<0.05)$ and occurred earlier $(P<0.05)$ on day 8 than on day 1 . The duration of $\mathrm{pH}$ drop was shorter on day $8(P<0.05)$, and the pH came back to basal value in all subjects on day 8 , but only in two of them on day 1 (Fig. 8).

\section{Discussion}

The intracolonic bacterial metabolism of unabsorbed carbohydrates is the matter of an increasing interest. It is the clue for interpretation of $\mathbf{H}_{2}$ breath tests, and it may be the source of both beneficial-caloric salvage-and adverse-induction of unpleasant symptoms such as excess gaz production effects. Relevant to these points, the consequences of a prolonged oral load of nonabsorbable sugars on the colonic bacterial metabolism of carbohydrates are debated $(1,7)$ : is this load inducing an inhibition, or on the contrary a useful adaptation of bacterial carbohydrate metabolism?

In the first part of the present study we evaluated the hypothesis formulated by Perman et al. (7) that chronic lactulose administration inhibits lactulose bacterial metabolism. The 24-h fecal excretion of lactulose and its constituent hexoses (fructose and galactose) was measured at the beginning and at the end of an 8-d oral load of lactulose with the same dosage as that used by these authors (7). Fecal sugar excretion was found to be very low and not statistically different between the two periods. These results could be anticipated because only one subject experienced initially a mild diarrhea, which disappeared within $3 \mathrm{~d}$, and because fecal $\mathrm{pH}$ was mildly acidic and did not vary between the two periods. Indeed, during malabsorbed carbohydrate administration, a relationship has

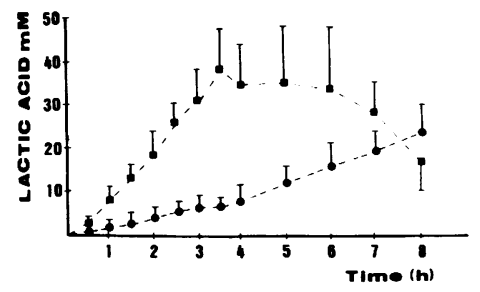

Figure 6. Lactic acid (D $+\mathrm{L})$ concentrations in cecal fluid after $20 \mathrm{~g}$ lactulose ingestion on day 1 (circles) and on day 8 after the lactulose maintenance period (squares) for four subjects. Bars represent the SEM. 
Table V. Fasting Total Concentration and Relative

Distribution of Cecal Fluid VFA on Day 1

and on Day 8 After the Lactulose Maintenance Period

\begin{tabular}{lllll}
\hline Day 1* & Day $8^{*}$ \\
\cline { 2 - 3 } Mean Range & Mean Range $\quad P$ \\
\hline
\end{tabular}

\begin{tabular}{|c|c|c|c|c|c|}
\hline $\begin{array}{l}\text { VFA mean } \\
\text { concentration } \\
(m M)\end{array}$ & 89.9 & $39-124$ & 52.8 & $20.1-79.8$ & NS $\ddagger$ \\
\hline Acetic acid (\%) & 56 & $39.2-66.4$ & 64.1 & $54.7-79.6$ & NS \\
\hline Propionic acid (\%) & 25.5 & $21.5-29.8$ & 22.8 & $8.9-29.9$ & NS \\
\hline $\begin{array}{l}\text { Butyric and } \\
\quad \text { isobutyric acid (\%) }\end{array}$ & 10.6 & $6.1-14.9$ & 8.9 & $6.1-11.4$ & NS \\
\hline $\begin{array}{l}\text { Valeric and isovaleric } \\
\text { acid }(\%)\end{array}$ & 0.7 & $0-2.9$ & 3.95 & $0-8.3$ & NS \\
\hline
\end{tabular}

$* n=4$.

$\ddagger$ NS, not significant.

been found between diarrhea, occurrence of the sugars in the stools, and drop of fecal $\mathrm{pH}(4,27)$. It is puzzling that in Perman et al. work (7), no diarrhea occurred in three out of four subjects in spite of a marked decrease of fecal pH. Thus, our findings do not support the hypothesis of an inhibition of colonic bacterial metabolism. However a drop of $\mathrm{H}_{2}$ breath excretion was observed between the beginning and the end of the lactulose maintenance period. It was less marked than in Perman et al. experiments, but still statistically significant. This last finding, together with the markedly increased fecal output of $\beta$-galactosidase activity, suggested a possible change in the metabolic pathways of bacterial sugar fermentation. This could represent an adaptation to the repeated colonic load of fermentable carbohydrates.

This hypothesis was confirmed by the second part of our experiments, comparing at the beginning and at the end of the lactulose maintenance period biochemical events occurring in the cecum following 20-g lactulose ingestion. Both peak concentration of lactulose and areas under the curves of lactulose, fructose, and galactose concentrations significantly

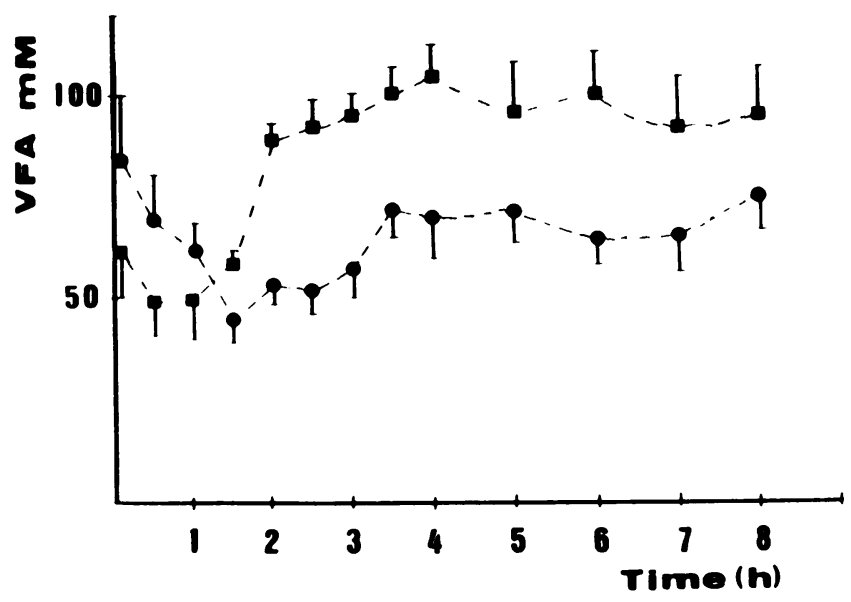

Figure 7. Total VFA concentrations in cecal fluid after $20 \mathrm{~g}$ lactulose ingestion on day 1 (circles) and on day 8 after the lactulose maintenance period (squares) for four subjects. Bars represent the SEM.
Table VI. Total Concentration and Relative Distribution of Cecal Fluid VFA After 20 G Lactulose Ingestion on Day 1 and on Day 8 After the Lactulose Maintenance Period

\begin{tabular}{|c|c|c|c|c|c|}
\hline & \multicolumn{2}{|c|}{ Day 1* } & \multicolumn{2}{|l|}{ Day $8^{*}$} & \multirow[b]{2}{*}{$P$} \\
\hline & Mean & Range & Mean & Range & \\
\hline \multicolumn{6}{|l|}{$\begin{array}{l}\text { VFA mean } \\
\text { concentration }\end{array}$} \\
\hline$(m M)$ & 66.5 & $49.4-92.5$ & 107.8 & $86-123$ & $<0.001$ \\
\hline Acetic acid (\%) & 59.2 & $53.1-72.9$ & 73 & $62.8-87.1$ & $<0.0001$ \\
\hline Propionic acid (\%) & 26.4 & $19.8-32.4$ & 16.8 & $8.7-22.8$ & NS $\ddagger$ \\
\hline $\begin{array}{l}\text { Butyric and } \\
\text { isobutyric acid (\%) }\end{array}$ & 11.9 & $7.2-15.8$ & 7.8 & $2.8-11.3$ & NS \\
\hline \multicolumn{6}{|l|}{ Valeric and isovaleric } \\
\hline acid $(\%)$ & 2.5 & $0-7.9$ & 2.4 & $0-3.9$ & NS \\
\hline
\end{tabular}

$* n=4$.

$\ddagger$ NS, not significant.

decreased from day 1 to day 8 . These findings may be explained in two ways: a shortening of the transit time in the right colon resulting in a quicker emptying of cecal content into the more distal colon $(27,28)$, or an increased velocity of bacterial breakdown of lactulose and of its constituent hexoses. The following statistically significant variations between days 1 and 8 favor the second hypothesis: (a) deeper drop of cecal $\mathrm{pH} ;(b)$ increase in areas under the curves of total VFA, acetic and lactic acid cecal concentrations; $(c)$ and increase in ${ }^{14} \mathrm{CO}_{2}$ pulmonary excretion. Increment in VFA and lactic acid cecal concentrations could not be accounted for by a decreased absorption rate, since the drop of intraluminal pH enhances the absorption of nonionic forms of these weak acids (29).

Our data not only strongly suggest a quicker bacterial catabolism of lactulose, but also support the hypothesis of a change in metabolic pathways. Indeed, $\mathrm{H}_{2}$ breath excretion decreased, whereas the molar ratio of acetic acid to total VFA and the concentration of lactic acid of cecal content increased significantly between days 1 and 8 . A decrease in $\mathrm{pH}$ of cecal content markedly favour the growth of lactic acid producing bacteria such as Lactobacillus, Bifidobacterium, and Eubacterium species $(14,19)$. These microorganisms are able to maintain an intracellular $\mathrm{pH}$ of 6.5 even in the presence of an extracellular $\mathrm{pH}$ of 3.5 or less (30). At such an acidic $\mathrm{pH}$ they remain good producers of $\beta$-galactosidase. The catabolism of carbohydrates by these bacteria increases acetic and lactic acid production, and thus is responsible for a markedly decreased $\mathrm{H}_{2}$ production

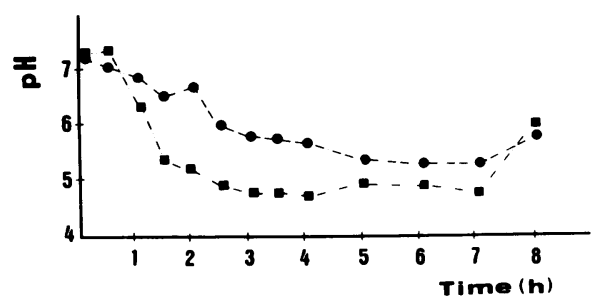

Figure 8. Mean cecal fluid $\mathrm{pH}$ following $20 \mathrm{~g}$ lactulose ingestion on day 1 (circles) and on day 8 after the lactulose maintenance period (squares) for four subjects. 
(11, 13, 14, 19, 30-32). Furthermore, the dome-shaped curve of lactic acid cecal concentrations at day 8 , contrasting with the plateauning of VFA levels, strongly suggests that chronic lactulose administration induced an increased number or activity of lactic acid-metabolizing bacteria. All studies on the effects of an oral load of nonabsorbable sugars failed to show any significant modification of bacterial flora populations ( 9 , 33), whereas studies of bacterial enzymes revealed marked changes $(14,31)$. However, the enormous complexity of fecal flora makes the demonstration of population level changes very difficult. The use of gnotobiotic animals harboring selected bacteria from human colonic flora could be of great help in demonstrating both bacterial population and metabolic activity changes.

\section{Acknowledgments}

We thank Mrs A. Bisalli for her excellent technical assistance and Mrs I. Batby for typing the manuscript.

\section{References}

1. Anonymous. 1982. The influence of colonic $\mathrm{pH}$ on the hydrogen breath test. Nutr. Rev. 40:172-179.

2. Bond, J. H., and M. D. Levitt. 1972. Use of pulmonary hydrogen $\left(\mathrm{H}_{2}\right)$ measurements to quantitate carbohydrate malabsorption. J. Clin. Invest. 51:1219-1225.

3. Bond, J. H., and M. D. Levitt. 1977. Use of breath hydrogen in the study of carbohydrate absorption. Am. J. Dig. Dis. 22:379-382.

4. Lifschitz, C. H., C. S. Irving, G. S. Copala Krishna, K. Evans, and B. L. Nichols. 1983. Carbohydrate malabsorption in infants with diarrhea studied with the breath hydrogen test. J. Pediatr. 102:371375.

5. Mac Lean, W. C., and B. B. Fink. 1980. Lactose malabsorption by premature infants: magnitude and clinical significance. J. Pediatr. 97:383-388.

6. Solomon, N. W., and F. Viteri. 1978. Development of an interval sampling hydrogen $\left(\mathrm{H}_{2}\right)$ breath test for carbohydrate malabsorption in children. Evidence for a circadian pattern on breath $\mathrm{H}_{2}$ concentration. Pediatr. Res. 12:816-823.

7. Perman, J. A., S. Molders, and A. C. Olson. 1981. Role of $\mathrm{pH}$ in production of hydrogen from carbohydrates by colonic bacterial flora: studies in vivo and in vitro. J. Clin. Invest. 67:643-650.

8. Newcomer, A. D., D. B. Mc Gill, P. J. Thomas, and A. F. Hofmann. 1975. Prospective comparison of indirect methods for detecting lactase deficiency. N. Engl. J. Med. 293:1232-1236.

9. Finegold, S. M., and V. L. Sutter. 1978. Fecal flora in different populations with special reference to diet. Am. J. Clin. Nutr. 31:S116S122.

10. Fuchs, H. M., S. Dorfman, and M. H. Floch. 1976. The effect of dietary fibers supplementation in man. II. Alteration in fecal physiology and bacterial flora. Am. J. Clin. Nutr. 29:1443-1447.

11. Gorbach, S. L., L. Namas, P. I. Lerner, and L. Weinstein. 1967. Studies of intestinal microflora. I. Effects of diet, age, and periodic sampling on numbers of fecal microorganism in man. Gastroenterology. 53:845-855.

12. Hill, M. J. 1981. Diet and the human intestinal bacterial flora. Cancer Res. 41:3778-3780.
13. Hill, M. J., M. J. Hudson, and S. P. Borriello. 1982. Factors controlling the intestinal flora. Eur. J. Chemother. Antibiotics. 2:5156.

14. Hill, M. J. 1983. Bacterial adaptation to lactase deficiency. In Milk Intolerance and Rejection. J. C. Delmont, editor. Karger, Basel. 22-26.

15. Vince, A., A. M. Dawson, N. Park, and F. O'Grady. 1973. Ammonia production by intestinal bacteria. Gut. 14:171-177.

16. Weber, F. L., K. M. Fresard, and B. R. Lally. 1982. Effects of lactulose and neomycin on urea metabolism in cirrhotic patients. Gastroenterology. 82:213-217.

17. Bornside, G. H. 1978. Stability of human fecal flora. Am. J. Clin. Nutr. 31:S141-S144.

18. Bornside, G. H., and I. Cohn. 1974. Stability of normal human fecal flora during a chemically defined, low residue liquid diet. Ann. Surg. 181:58-60.

19. Gottschalk, G. 1979. Bacterial fermentation. In Bacterial Metabolism. Springer-Verlag Inc. New York. Heidelberg. Berlin. 167224.

20. Haines, A., G. Metz, J. Dillawari, L. Blendis, and H. Wiggins. 1977. Breath methane in patients with cancer of the large bowel. Lancet II:481-483.

21. Pitt, P., K. M. Debruijn, M. F. Beechinc, E. Goldberg, and L. M. Blendis. 1980. Studies of breath methane: the effect of ethnic origins and lactulose. Gut. 21:951-959.

22. Abt, A. F., and S. L. Von Schuching. 1966. Fat utilisation test in disorders of fat metabolism. A new diagnostic method applied to patients suffering with malabsorption syndrome, chronic pancreatitis and arteriosclerotic heart disease. Bull. Johns Hopkins Hosp. 119:316330.

23. Bush, K. J., R. W. Russel, and J. W. Young. 1979. Quantitative separation of volatile fatty acids by high pressure liquid chromatography. J. Liq. Chromatogr. 2:1367-1374.

24. Marhun, D. 1976. Rapid colorimetric assay of $\beta$-galactosidase and $\mathrm{N}$-acetyl- $\beta$-glucosamidinase in human urine. Clin. Chim. Acta. 73:453-461.

25. Yuen, C. T., R. G. Price, L. Chattagoon, A. C. Richardson, and P. F. G. Praill. 1982. Colorimetric assays for N-acetyl- $\beta$-Dglucosamidinase and $\beta$-D-galactosidase in human urine using newly developed $\omega$-nitrostyryl substrates. Clin. Chim. Acta. 124:195-204.

26. Solomon, N. W., F. E. Viteri, and L. H. Hamilton. 1977. Application of a single gas chromatographic technique for measuring breath hydrogen. J. Lab. Clin. Med. 90:856-861.

27. Saunders, D. R., and H. S. Wiggins. 1981. Conservation of mannitol, lactulose and raffinose by the human colon. Am. J. Physiol. 241:G397-G402.

28. Chauve, A., G. Devroede, and E. Bastin. 1976. Intraluminal pressures during perfusion of the human colon in situ. Gastroenterology. 70:336-340.

29. Ruppin, H., S. Bar-Meir, K. Soergel, C. M. Wood, and M. G. Schmitt. 1980. Absorption of short chain fatty acids by the colon. Gastroenterology. 78:1500-1507.

30. Padan, A., D. Zilberstein, and S. Shuldiner. 1981. pH homeostasis in bacteria. Biochim. Biophys. Acta. 650:151-166.

31. Simon, G. L., and S. L. Gorbach. 1984. Intestinal flora in health and disease. Gastroenterology. 86:174-193.

32. Smith, C. J., and M. P. Bryant. 1979. Introduction to metabolic activities of intestinal bacteria. Am. J. Clin. Nutr. 32:149-157.

33. Hentges, D. J. 1978. Fecal flora of volunteers on controlled diets. Am. J. Clin. Nutr. 31:S123-S124. 